\title{
水利工程施工中的生态环境问题及对策探究
}

\author{
吕晓恒 \\ 昌吉市水通设计监理有限责任公司 \\ DOI:10.32629/hwr.v4i4.2874
}

[摘 要] 水利工程施工的复杂性较强, 施工周期较长, 对工程周边的生态环境也产生较大影响,进而产生水污染、噪音污染和固体废弃物污染。 为改变现状,应采取科学有效的应对策略。

[关键词] 水利工程; 生态环境; 问题及对策

现如今, 我国水利工程建设日益完善, 工程数量和工程规模均呈上升 趋势, 但在水利工程施工中也出现了诸多的生态环境问题, 不利于工程建 设的可持续发展。为此, 应客观看待水利工程施工中的生态环境问题, 并采 取科学的应对策略。

\section{1 水利工程施工中的环境问题}

1. 1 大气污染。大气污染是水利工程建设中较为常见的污染形式, 主要 是因为水利工程施工中使用的生物和化学用品燃烧会产生大量的有害气 体, 进而出现大气污染。另外, 使用水泥砂石等建筑材料的过程中会产生大 量的扬尘, 进而产生粉尘污染。如施工人员或周边居民吸入含有大量污染 物的空气, 则会直接威胁人体健康。

1.2 水体污染。水环境问题也是水利工程施工中较为常见的环境问 题, 主要包括生物污染、施工污水、水环境问题等。工程施工多为临时 驻地, 故而出现生活污水未经处理随意排放以及施工垃圾随意堆放等问 题, 这严重破坏了施工现场的生态环境。同时, 工程项目建设及大型机械 设备运行的过程中, 泄漏的油污直接排放至当地水域中, 也会引发水体 污染。

1. 3噪声污染。水利工程项目施工中需要使用多种类型的机械设备, 设备运行时会产生较大的噪声, 若施工人员长期处于噪声环境中, 则将损 害施工人员的听力水平, 并对周边居民的日常生活造成较大干扰。

1. 4 固体废弃物污染。固体废弃物污染在水利工程项目建设中尤为 常见, 出现上述问题主要与作业中挖出大量废弃土体有关。若水利工程 项目建设和施工中无法建立科学的应对机制, 则会引发严重的环境污染 问题。同时, 工程施工中剩余的石灰粉、水泥和煤灰也会对生态环境造 成负面影响。

1. 5 土地浪费。水利工程施工期间, 若无法合理堆放施工材料、未按要 求搭建设施和房屋, 则会占用大量土地资源, 一方面破坏水利工程施工现 场的生态环境, 另一方面也会产生较为严重的水土流失问题。

\section{2 生态环境问题的成因}

2. 1缺乏环保意识。缺乏环保意识是引发环境问题的关键要素。现阶 段, 很多施工企业均无法正确认识环境保护的作用和价值, 因此在工程建 设中经常出现随意排放和处理废弃物等现象, 进而引发多种形式的环境污 染问题。再者, 部分施工企业在工程建设中过于关注经济利益和施工速度, 忽视了环境建设, 破坏了生态平衡。

2. 2环保管理有待改善。工程施工中, 虽然很多企业均开展质量管理和 进度管理, 但却忽视了环保管理, 无法在第一时间发现并解决施工中的环 境问题。部分企业虽然落实了环保管理, 但并未深度分析水利工程环境问 题, 所以也无法充分发挥环境管理的积极作用。

2.3 专业技术有待提升。当前, 水利工程施工中, 出现了诸多环保施工 技术和新型环保材料。但部分施工企业在发展中依然采用传统施工材料和
传统的施工技术, 并未及时应用新技术新材料, 进而一定程度的影响了生 态环境保护工作的落实效果。

\section{3 水利工程施工中生态环境问题的解决对策}

3. 1 增强环保意识。在水利工程施工中, 应增强施工人员的环保意识, 减少环境污染问题。项目管理人员和现场施工人员需深化自身环保意识, 正确认识环境保护的积极作用。施工单位要加大技能培训力度, 开展系统 的环保教育培训, 使施工人员意识到环境保护的重要作用。管理人员需及 时调整对生态环境影响较大的施工方案, 完善施工计划, 加强环境保护。

3. 2 建立完善的生态体系。基于水利工程项目生态价值, 促进水利工程 与生态工程的协调发展成为当前水利工程建设中的重要内容, 为此, 就应 将生态环境作为立足点, 在水利工程施工中建立系统的生态工程体系, 加 大环境保护力度, 并践行工程废料及污水处理机制。除此之外, 还需注重水 利工程与环境工程的有机统一, 构建完善的生态工程体系和生态资源管理 模型, 这是促进工程项目与生态环境协调发展的重要基础。

3. 3优化废弃物处理。施工单位需按照环境污染防治法的规定处理施 工中的废弃物和生活垃圾, 并将其运送至指定气渣场, 确保施工区和生活 区的环境清洁, 且施工区和生活区要设置多个临时垃圾箱, 定期清运垃圾, 按照要求对垃覆土填埋。

3. 4 提高技术水平, 减轻环境污染。科学的施工技术是处理环境污染问 题的重要措施之一。施工单位可从国外积极引入先进技术和设备, 提高材 料利用率, 有效减轻环境污染。此外, 合理利用更为先进的垃圾处理技术, 有效减轻垃圾对环境的负面影响。如针对施工中产生的空气污染问题, 可 采用封闭式垃圾道来处理, ; 对于噪声污染, 则要严格控制施工时间, 并设 置围挡设施, 以此将噪声污染对周边居民的影响降至最低。

3. 5 加大环境监测力度。水利工程企业应加强环境监测, 减轻环境污 染。施工企业需优化监测仪器, 合理利用专业的设备和仪器完成环境监测 工作, 且综合分析环境监测结果, 明确施工中的环境问题, 进而采取科学有 效的解决措施, 推动水利工程建设与生态环境的和谐发展。

\section{4 结语}

因为水利工程施工中会产生多种污染问题, 对此, 施工单位就需要加 大管理力度, 并采取多种措施保护工程周边的自然环境, 以此保障水利工 程建设与自然环境的和谐发展。

\section{[参考文献]}

[1]骆向伟.水利工程施工中生态工程的环境措施问题 [J].现代物业 (中旬刊),2018(02):62.

[2] 李强. 水利工程施工中生态工程的环境问题分析 [J]. 门 窗,2018(03):104.

[3]李永刚.水利工程施工中生态工程的环境措施问题 [J].现代物业 (中 旬刊),2018(12):253. 